Portland State University

PDXScholar

1983

\title{
The relationship between Romanes and English as spoken by the Portland Gypsies
}

\author{
Margaret Anne Sharp \\ Portland State University
}

Follow this and additional works at: https://pdxscholar.library.pdx.edu/open_access_etds

Part of the Linguistic Anthropology Commons, and the Social and Cultural Anthropology Commons Let us know how access to this document benefits you.

\section{Recommended Citation}

Sharp, Margaret Anne, "The relationship between Romanes and English as spoken by the Portland Gypsies" (1983). Dissertations and Theses. Paper 3397.

https://doi.org/10.15760/etd. 5280

This Thesis is brought to you for free and open access. It has been accepted for inclusion in Dissertations and Theses by an authorized administrator of PDXScholar. Please contact us if we can make this document more accessible: pdxscholar@pdx.edu. 
AN ASSTRACT OF THE THESIS OF Margaret Anne Sharp for the Naster of Arts in Anthropology presented May 12, 1983.

Title: The Relationship Between Romanes and English as Spoken by the Portland Gypsies

APPROVED EY MEMBERS OF THE THESIS COMNITTEE:

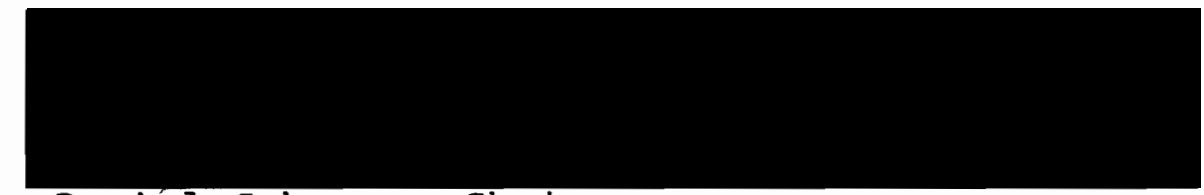

Daniel Scheans, Chairman

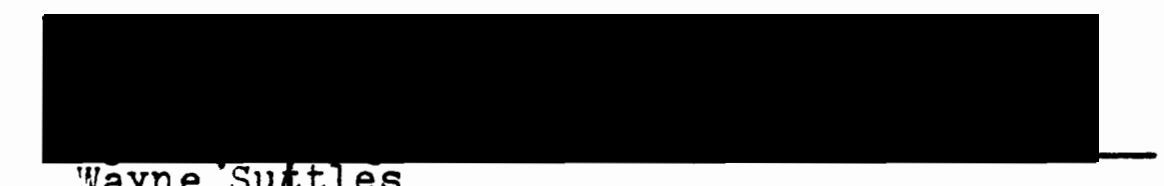

Wayne Suftles
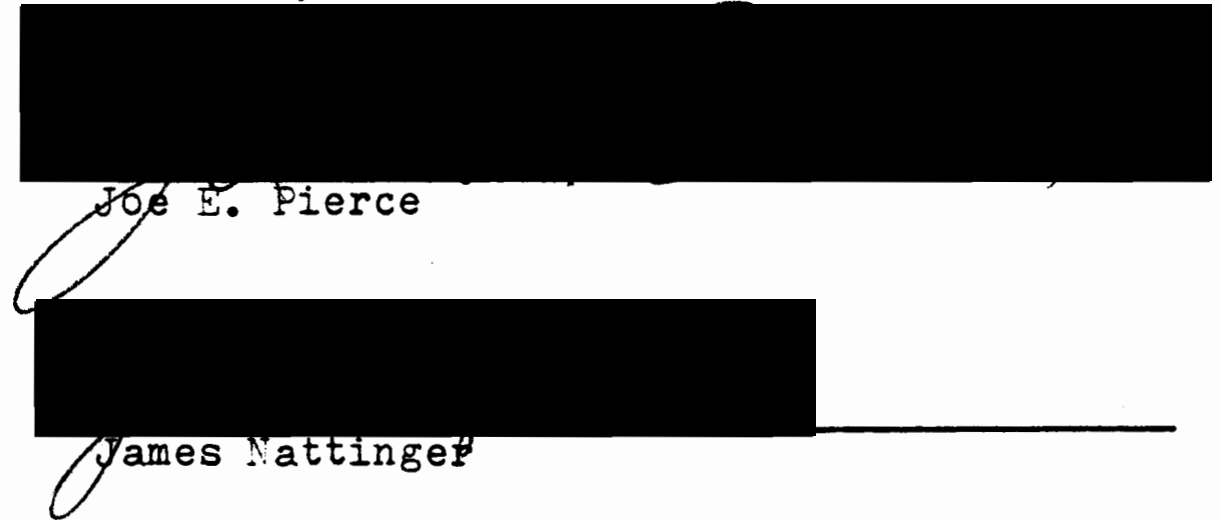

This thesis examines the relationship between English and Romanes as spoken by the Portland Kalderash Rom (Gypsies). Examples, taken from natural conversations which were taped, translated, and analyzed, show that the intermixing follows rules which guard the linguistic integrity of both languages. Code changing, code mixing, linguistic 
natural setting. A lexicon of Romanes words, elicited from members of the Gypsy community, is also included. The findings of this study support the thesis that this intermixing of Romanes and English is adaptive in that it insures that all members of the community can speak both languages from an early age.

It is further submitted that this method of language learning is necessary because children learn English from their parents and other older family members, not from their peers. 
THE RELATIONSHIP BETWEEN ROMANES AND ENGLISH AS SPOKEN BY THE PORTLAND GYPSIES by

MARGARET ANNE SHARP

A thesis submitted in partial fulfillment of the requirements for the degree of

\author{
MASTER OF ARTS \\ in \\ ANTHROPOLOGY
}

Portland State University

1983 
TO THE OFFICE OF GRADUATE STUDIES AND RESEARCH:

The members of the Committee approve the thesis of Margaret Anne Sharp presented Nay 12, 1983.

\section{Daniel J. Scheans, Chairman}

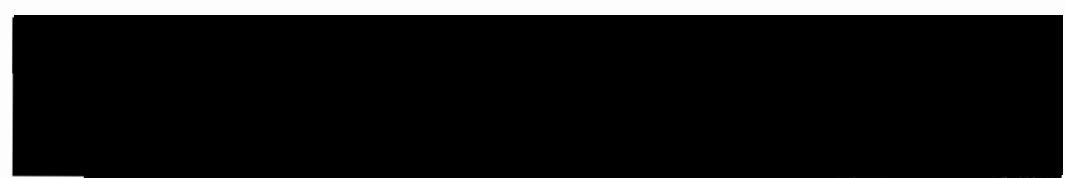

Wayne Suttles

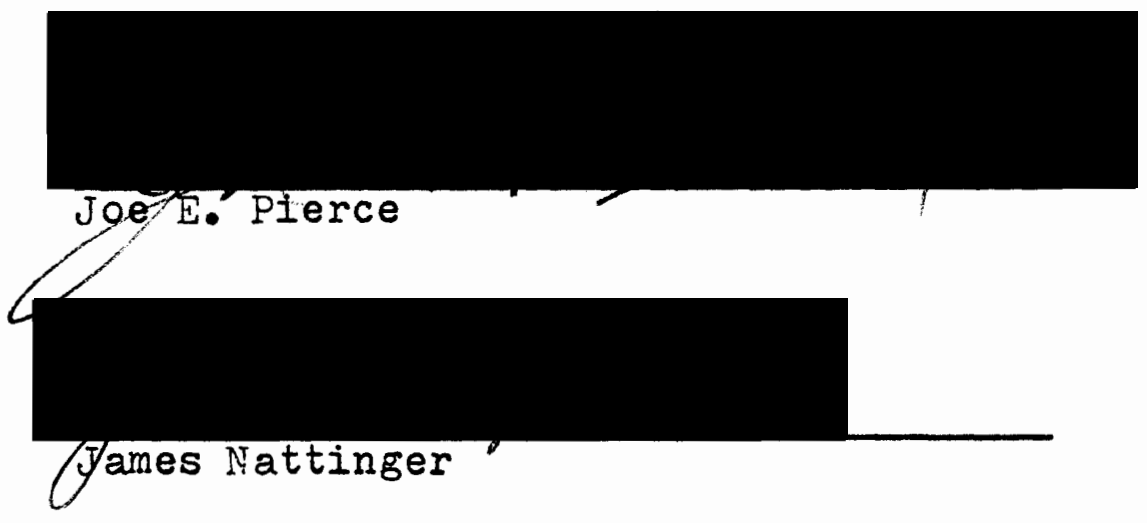

APPROVED :
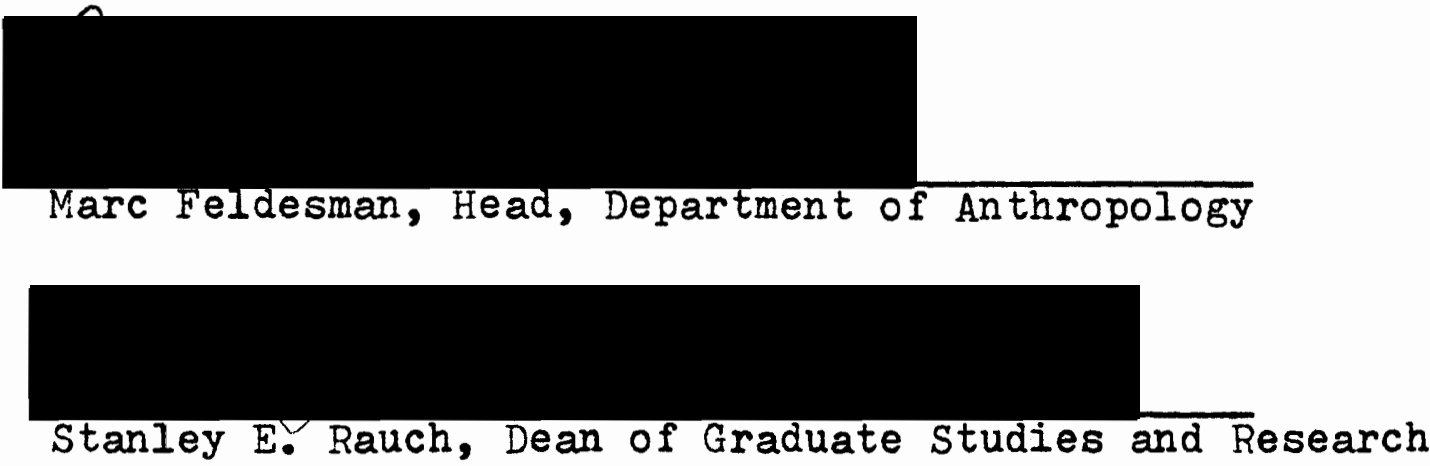


\section{ACKNOWLEDGEMENTS}

The help of many people has made this study possible. First of all, I gratefully express my appreciation to my principle teacher, Joann, Baraska le Janeski hai Vičiki, and the immediate and extended members of the John King Ellis family, who gave me more than mere linguistic information.

I would like to thank the members of my committee, Dr. Daniel Scheans, Dr. Wayne Suttles, and Dr. Joe Pierce, for agreeing to serve on my committee.

I have benefitted from the expertise of the following people who have volunteered time, materials, and, especially their interest and encouragement: Dr. Werner Cohn, Charles Council, James Garlock, Merle Grant, Dr. John Richards, Chet Romig, Dr. Carol Silverman, and Dr. Wayne Suttles. 
TABLE OF CONTENTS

ACKNOWLEDGEMENTS • • • • • • • • • • • • • iii INTRODUCTION . . . . . . . . . . . . . 1 RELATIONSHIP BETWEEN ROMANES AND ENGIISH • • • • 8 Code Switching . . . . . . . . . 8 Code Changing . . . . . . . . . 12 Linguistic Constraints . . . . . . . 17 Interference . . . . . . . . . . 19 other Characteristics . . . . . . 30

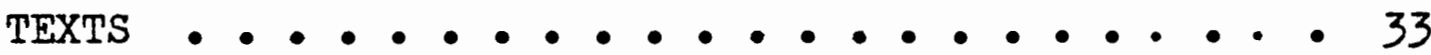
Conversation one . . . . . . . . 33 Conversation Two . . . . . . 34 Conversation Three . . . . . . . 37 Narrative . . . . . . . . . 46 IEXICON •. . . . . . . . . . . . . . 51 SOURCES CITED •. . . . . . . . . . . 65 


\section{INTRODUCTION}

Bilingualism has long been an interest of linguists. Studies have yielded important information on language learning (Bain and Yu 1980 and Ervin and Osgood 1954), the structure of language (Paradis 1978 and Lipski 1980), and the structure of the brain (Vaid and Genesee 1980). Despite so much information on bilingualism, for a long time it was thought that any intermixing of two or more languages was the result of faulty learning (Weinrich 1963) or faulty brain mechanisms (Kolers 1963 and MacNamara 1967). Only recently with Rayfield (1961), Haugen (1972), Clyne (1980), and Sridhar and Sridhar (1980), studies have shown that this is not necessarily the case. When examined, as this intermixing recently has been, grammatical structures have been found which add more information to the answers to the traditional questions about language learning, the structure of language, and the structure of the brain. In addition, new discoveries on the language mixing of bilinguals better illuminate ways in which monolinguals use paralinguistic communication devices.

Many bilingual situations are temporary, brought about by immigration to a new area. The third generation has often lost the language of its grandparents. Most of 
the speakers studied by Rayfield (1961), Haugen (1972), and Clyne (1980) spoke transplanted languages which had once been the primary languages of larger groups. The studies show how these speakers mix this "second language" with the dominant language of their new home. Often the mixing is due to imperfect memory of the language of the speakers' ancestors.

Other studies have shown that two or more languages can be maintained by a community of speakers. Many groups keep the languages separate, using them in separate social situations (Wolck 1973 and Rubin 1968). This separation of languages was called "ideal" diglossia (Weinrich 1963). Any mixing was thought to show an "unstable" language situation (Greenfield and Fishman 1972).

It is my thesis that the mixing of Romanes and English, as the languages are spoken by the Portland Kalderash Gypsies, is not due to imperfect learning of either language, but is a beneficial way of insuring that all members of the community know both languages from an early age. While English is essential for economic survival, Romanes continues to be important for cultural solidarity. The mixing of the languages follows rules which show that mixing is not random and does not lead to general confusion of the grammar of either language.

Field Methods

The literature on Gypsies abounds with warnings of 
the hostility which Gypsies feel toward non-Gypsies and despairs of the ease or even the possibility of working with them (Maas 1975: 195; Pickett 1970: 2, 220; Sutherland 1975: 21; and Yoors 1967: 50-1). Anthropologists have found Gypsies to be especially secretive about their language (Gropper 1981: 4 and Silverman 1979: 11). Despite these gloomy predictions, I found the Gypsies with whom I worked to be helpful and encouraging in my language studies.

Educator James Garlock, project co-ordinator for the Portland Public Schools' Gypsy education project, introduced me to John Ellis, who bills himself as King of the Western Gypsies of North America. When I explained that I wanted to learn about the Gypsy language, he offered to have his daughter Joann teach me. He accepted my offer of $\$ 4.50 / \mathrm{hr}$. without further negotiation.

Although Joann was my principal teacher, the whole family contributed knowledge and opinions. Dozens of visitors also generously helped and encouraged me. We began with simple word lists and memorized dialogues as I learned about the language. Joann then taped natural conversations in her home and on trips. These tapes show how English and Romanes are used in everyday conversation. Together we translated sixteen hours of taped conversations. I then analyzed the material to find patterns of intermixing. 
The fieldwork took place from May 1981 until December 1982. Our schedule was very erratic, but averaged three hours of linguistic study per week plus an additional four or five hours of general ethnographic participation and observation.

\section{Language Description}

Romanes, the Gypsy language, is descended from Prakrit which was a vernacular of Sanskrit (Gropper 1975: 1-2). The English translation for Romanes is Romany or simply Gypsy. Gypsies in the Portland area mainly speak the Kalderash dialect which is one of the Vlax group of Gypsy dialects. Vlax dialects are spoken by those whose ancestors spent several centuries as slaves in Romania and consequently were considerably influenced by the Romanian language (Hancock 1975).

Romanes is not a standardized language (Hancock 1975) and there is no one recognized standard alphabet (Kendrick 1981). Although there is much talk among Gypsy nationalists about developing a universal standard for literature and better communication among Gypsies from different countries, the Gypsies with whom I talked feel that it is not necessary. They feel that they can understand and be understood by any Gypsy in the world.

Ideas about a literary language vary among Portland Gypsies. Most see no need for a written system. In fact, some feel that it is impossible. Yet one man tested my 
knowledge of Romanes by writing a sentence using English phonetics. At the beginning of our work, Joann showed off my progress by having me speak to different people. Reading the words was just as impressive as saying them from memory. Many remarked that they didn't know it was possible to write Gypsy words. Although it's a good trick, the very writing of Romanes is not seen as useful. Many get along fine without even writing English. No one writes to another in Romanes. It is not even seen as a way to preserve the language for those who have lost it. It is believed that the only way to preserve the language is to continue to use it as it is now used.

The English language is referred to as American. Non-Gypsy people are Gaze, a word which is usually more narrowly translated into English according to the persons referred to, such as American or Mexican. Although the Portland Gypsies are American citizens, they separate themselves culturally, referring to themselves as Gypsies, when speaking English, as opposed to Americans.

\section{Mixing Romanes and English}

Although all members of the Gypsy community in Portland are fluent in both Romanes and Inglish, most of the conversations within the community consist of a mixture of Romanes and English. I believe that this intermixing is 
adaptive in that it insures that all members can speak both languages.

Much has been written about the best methods for bilingual learning. Ronjat's principle of one parent: one language is believed by many to be necessary for mastery of complete differentation between two languages at an early age (Bain and Yu 1980). Kolers and Paradis (1980: 289) broaden this theory by stating,

One might try to generalize the principle to maintain that any condition that served to set a language apart would do, such as using one language only in one set of circumstances and the other in other defined circumstances.

Besides separating the languages for better learning, some linguists feel it is needless to use two languages within the same group of people at all. Haugen (1977: 98) writes, "It is clearly inefficient to maintain two systems in addressing the same speech partners."

The Gypsy community in Portland uses an alternative method for insuring fluency in two languages. Both of the languages can be used in a conversation and even within a sentence. The mixing follows rules which insure the integrity of each language. Granted, the English spoken is not standard English and there is interference from both languages onto the other, still everyone can use different styles and nuances appropriate in both languages. (This intergenerational use of the same non-standard items in English is a further proof for my thesis that English is 
learned from parents and other elders in the community and not from television as Rubin (1980) suggests.) The results of this method of bilingual learning compare favorably with the highly structured Ronjat method used in more formal bilingual training (Bain and Yu 1980). The proof is that children as young as three and four follow the rules of language mixing and separation.

Al though many bilingual children learn English from their peers, Gypsy children are isolated from non-Gypsy children. They spend most of their time in family groups with members of various ages instead of narrow age groups. This cultural difference accounts for the greater influence of parents on the speech of their children. 
THE RELATIONSHIP

BETWEEN ROMANES AND ENGLISH

Code Switching

Portland Gypsies alternate between Romanes and English. According to Uriel Weinrich (1963) an "ideal" bilingual is one who uses the languages in separate social situations. This ability is called diglossia. Many studies have shown that some groups of bilingual speakers actually do keep their languages separate (Greenfield and Fishman 1972, Wolck 1973, and Rubin 1968). It was once thought that the mixture of two or more languages was the result of a confusion between the languages caused by imperfect learning or a faulty brain mechanism. Mixing of the languages was seen as a stage on the way to developing a creole or a sign of acculturation as the "pure" language was "lost" (Fishman 1964: 51-2).

Recent studies show that code switching is not the random degeneration it was once thought to be. More and more research has found that switching between languages is common among those who speak independent languages. Sridhar and Sridhar (1980: 408) write,

In fact, under certain circumstances (e.g. when all the participants in a speech situation share a bilingual background) code mixing may be the norm rather than the exception. 
Rules have been found for code switching as they have for diglossia. These rules serve to keep the languages independent while allowing the use of both language systems. Sridhar and Sridhar (1980) call this kind of bilingualism "interactionist".

The various methods for alternating between the languages are grouped under the heading code switching by McClure and McClure (1975). Code switching is further divided into code changing, which is change from one language to another to convey sociolinguistic messages, and code mixing, which has no known function, but which still follows rules or linguistic constraints.

Portland Gypsies may switch languages at any time. It is rare to hear someone speak for any length of time without switching. This switch may be continued for several sentences, a phrase, or just a single word. Yet any Gypsy can speak entirely in English or in Romanes when the situation calls for it.

There are two situations which call for speaking in only one language. One is when those spoken to are not Romanes/English bilinguals. Visitors who do not speak English, e.g. from Mexico, are spoken to entirely in Romanes although it may be hard to keep English from creeping in at times. The same situation applies to those who are visiting another country. Again, Mexican Gypsies are the most commonly visited non-English speakers. 
Americans are spoken to in English only. This is for convenience with strangers and politeness with friends. "We don't want to 'barrass our friends." Speaking in English makes an American part of the discussion even when he is not directly spoken to. One day when a group of us were "testing" everyone who came over as to whether they would first speak in Romanes or English, a man defended himself from the teasing by saying that he had spoken in English "because a lady is here", referring to me. English is thought to be harder to speak without any Romanes when talking with a Gypsy than when talking with an American. "With you I talk American perfect, but with my friends... I can't do it, even that I tryl" Because of practiced Iimitation to one language, it is easier for Gypsies to speak using only one code with Americans than it is when speaking with other Gypsies whether or not they speak English.

When talking about an American who is present, Gypsies speak Romanes. "Say I want to make fun of you. Then I speak Gypsy." Those who saw me for the first time would often ask about me in Romanes. They were always answered in Romanes even though Joann's family knew I could understand what they were saying. Of course, most of the time that they speak Romanes, it is just natural without the act being a matter of secrecy. 
The other time when only one language is spoken is when Romanes is used to show socio-cultural authenticity in order to demonstrate authority. For example, during a kris ( a Gypsy trial), the leader gives a speech which is supposed to be completely in Romanes. When I asked why, I was told, "Because he wants everyone to listen to him." He tells what the rules are. The authenticity of these laws throughout the ages is represented by speaking only Romanes.

Another example of Romanes providing authenticity is the material of the Gypsy evangelist who visited Portland in 1981 (for an example, see Jesus King of the Gypsies n.d). The talks, tapes and videotape were entirely in Romanes. Other visual assurances such as the extended family, the tables of food, and the traditional greetings were additional evidence of true Gypsy leadership. Another videotape (Fox 1978) which showed Gypsies was greeted sceptically by some because they didn't speak Romanes during the tape.

I believe it is this feeling of authority as well as the emotion which influenced most anger to be expressed in Romanes. The only time I heard a Gypsy being reprimanded in English, it was for my benefit: the boy was chastised for keeping me waiting. Even when a Gypsy was speaking to an American, his voice became lower and his sounds were more front-rounded as if he was speaking Romanes. 
Speaking entirely in Romanes in ordinary conversation is not common, but it doesn't seem to be thought of as "showing off" as is the case for some Spanish/English bilinguals ( $P$ faff 1979: 293).

Code Changing

Changing from one language to another is often a stylistic device which has a sociolinguistic function. The Portland Gypsies use code changing in several ways. 1. To attract attention.

This may be as simple as using two names when calling someone. "Joann! Barasko! [Vocative of Baraska] " Other times it is used to claim the speaking turn in a conversation. Turn taking has been explored for monolinguals (Duncan 1972; Schegloff 1968; and Meltzer, Morris and Hayes 1971). As with monolinguals, Gypsies may seek attention by raising the voice (Meltzer, Morris and Hayes 1971) or by changing lexical items when repeating (Schegloff 1968). They also have the option of attracting attention by code changing. Several methods may be used until one gains the speaking turn. "Iis to this, Doris. Barbo, lis to this. Ǎsuna kako. Listen to this.

Iisten to this. This is the best part." 
2. To set off quotations.

phєndém ĺaka, "We can't stay."

[I said to her]

Ǎsudém, "Don't bring Teri."

[I heard]

Phendem Paiźano, "What's the matter with you?"

[John said]

She called me up: "Mangáu kris. Karés kris."

[I want a trial. Make a trial.]

We're not doing anything for her.

Sentences attributed to another, though not direct quotations, can be set off through code changing.

So phends] they're gonna make it right away?

[What if he says]

This doctor will probably say

ci mangsl te karel o operation.

[he doesn't want to do the surgery]

3. For effect or efficiency.

A word in one language may express an idea more effectively or efficiently.

"A Gazi wants you." is easier than "An American woman wants you."

Complaining about the take-out food they had brought home, a man said, "I can't believe we paid for this." A woman answered, "We had xabe (food) in the icebox." In this case, 
using the Gypsy word for food implies good food.

In Romanes, pronouns are often unnecessary because person is understood in verb forms. Inclusion is then sometimes used for emphasis:

"Kon san?" "Me Yana. Kon san tu?"

["Who are you?" "I'm Anne. And who are you?"]

Therefore, a Romanes pronoun in an English sentence shows added stress on the pronoun.

"She didn't kiss him. How 'bout tu?"

4. For emphasis.

Code changing can emphasize a point.

"It looks more like merikánsi (American)."

"Delores looks very šuki (skinny)."

Sometimes repetition and code changing are used together. "Kai ges? Where are you going?"

[Where are you going?]

"How about Frank?" "Who?" "으 Frankie."

"Kai gel? Is he going to a party?"

[Where's he going?]

"Das duma o telefono. Yeah, call up to the phone." [Talk to the phone (company).]

Using a different language for question words emphasizes them similar to the way English monolinguals would put extra stress on the word. 
"How but buslen?"

[How long did they stand there?]

"Why roésa arát?"

[Why did you cry last night?]

"Why mangás zauwe kerí?"

[Why do you want to go home?]

"So mean?"

[What do you mean?]

5. To set off and explain.

"Now this is the best part, oh, Doris.

Barbo, this is the best part.

Śuka asel Rocky áno ṕarno suto.

[Rocky looks so good in his white suit.]

Suka asel Rocky ano kalo suto hai parno gad.

[Rocky looks so good in his black suit and white shirt.]

Hai phidél î stairs."

[And he walks down the stairs.]

"The only thing saves you. You know what saves you?

Kai dobi."

[That you win.]

"I was going to say something.

Avilé tut i Joann?

[Has Joann come (to you)?] 
Mangáu triu o fistáno kai kind'́m

(I want to try on the dress that I bought (to see if)

ftila."

it fits.]

"You know he puts out a good show. So sas?"

[How was he?]

"Everyone's joining us, yo Waso?"

[And you, Walter?]

"I think mang'́l te karél but darźda."

[He wants to make alot of money.]

"I wish či kindśm o xab́e."

[I hadn't bought the food.]

6. Linguistic routines.

Hasselmo (1970) states that "linguistic routines"

such as idioms and stock phrases and other pre-formulations are most easily used in the form in which they were first heard. In fact, some words and phrases used by the Portland Gypsies are always heard spoken in just one of the languages.

"Hai two for iive."

[And two for five.]

"Ḿla one hundred thrity-nine dollars."

[They're worth....]

"A yoi dali, it's a fortune!"

[Oh, Mother...] 
"Paikif tuka."

[Honor to you.] A ritual phrase used when a young woman dances for someone. "It's an honor to dance for you."

"Čačimos."

[Truth]

Said when someone sneezes.

\section{Linguistic Constraints}

Although not all code switching is found to have a function, all switching follows certain rules. There are linguistic constraints which function to avoid switching which would violate the rules of either language.

\section{Clauses.}

The most common time to change languages is at the clause. The conjunction usually belongs to the language of the second clause.

"Ǵuli murú deŕesa and I can't find them."

[She went with my father....]

"Wopcl le draba and he cheats."

[He takes pills.... (medicine)]

"Farbosadem and then they're roofin' it."

[They painted....]

"It's miserable hai nai kai gEs,"

[... and there's no place you can go.] 
2. Phrases are common places to switch.

"When you want them nai khote."

[... they're not there.]

"This doctor will probably say

či mangél te kaŕ́l o operation.

[...he doesn't want to do the .....

3. Single words.

Nouns are the most common single English words to be used, often because there is no known Romanes equivalent. "Windshield khrakisáidi."

[The windshield cracked.]

"Mangáau hot dog."

[ I want.... ]

Romanes nouns with unknown equivalents occur, but this is not common.

Adjectives and interrogatives are commonly used alone for emphasis. Less often are pronouns and adverbs. (See above for code changing.)

Words with attachments are not used alone. The attachments must be in the same language so that no rules of grammar are broken. For example, the word "chopsticks" has no Romanes equivalent nor has it become assimilated into the Gypsy language. Therefore, it cannot be used as a Romanes word can be. "Sai xas tu with chopsticks?" [Can you eat....] 
Mixing of the two languages to form the hybrid form "chopsticks-sa" (with chopsticks) is not allowed. English grammatical rules are also not violated. For example, Paiźano's American name is rarely used. Therefore, the speaker of the following sentence switched to Romanes to show possession instead of using the English form on a Romanes word. "You know Doris, Paizanóski fat one.

$$
\text { [... John's ....] }
$$

\section{Interference}

Despite many generations of co-existence with English, Romanes has experienced little interference. Lexical interference is to be expected since Romanes is a living, growing language which must add lexical items in order to be functional in this new environment. Interference may be encountered at four levels: phonetic, structural/phonetic, lexical, and structural.

1. Phonetic interference. (In this analysis and throughout this paper, I will use slash marks to show probable phonemics al though their use does not signify that the sounds therein are the product of a detailed phonemic analysis. Brackets will indicate English translations of Romanes.)

There is little phonetic interference from English to Romanes. / $æ /$ is present especially, although not exexclusively, in English loanwords. 
bæega bag, sack

stregi hat

2. Structural/phonetic interference.

There is possibly some relaxed strictness on stress in some words. Yet some words are completely not understood when the stress is in the wrong place. Words which could be confused if vowel length and accent were relaxed are especially stressed.

Dadi Daddy

3. Lexical interference.

Most loanwords are structurally modified.

Nouns: The most common modification is simply Romanes pronunciation and the addition of a final vowel.

\begin{tabular}{|c|c|c|c|}
\hline fárma & farm & freno & friend \\
\hline b́akso & box & bes skéta & basket \\
\hline doktóoro & doctor & śkula & school \\
\hline strito & street & saláata & salad \\
\hline
\end{tabular}

Some modifications involve the loss of a syllable or a phoneme.

$\begin{array}{llll}\text { mó́bili } & \text { car } & \text { kona } & \text { corner } \\ \text { piśtalo } & \text { hospital } & \text { oráit } & \text { alright }\end{array}$

Some nouns are modified extensions of English words.

$\begin{array}{llll}\text { yárdo garden } & \text { satino silk } \\ \text { ǵ́obl } & \text { light bulb } & \text { ḱhario } & \text { van }\end{array}$

Verbs: Verbs are generally modified only by Romanes endings. 
"Khalu papale."

"Mangáu triu 의 fistano."

"Digasad́sm gŕapa."

"Sas filiz orát?"
I'll call back.

I want to try on the dress.

I dug a hole.

Do you feel alright?

Adjectives: Adjectives also take on the Romanes form.

"Desa hapila."

She's very happy.

"Ékla."

She's fake.

"Bordmánga."

I'm bored.

"Orselisa."

I'm thirsty.

4. Structural interference.

Although even Gypsies with no formal education can put Romanes sentences into English structure to make it easier for me, this structure is not normal. The only structure which follows English is the occassional use of a form of the verb "to go" to indicate future tense. The future tense is more traditionally the same as the present (Gjerdman and Ljungberg 1963: 109).

"Zau te dobi loẃe."

I go that I win money

[I'm going to win money.]

"Zau ažukaráu dau kerí $\underline{\text { zau te lasarál }}$

I go I wait I give at home that he fixes

[I'm going to wait at home for the man who will fix

ㅇ telefóno."

the telephone

the telephone.] 
Romanes Interference in English

In contrast to the small amount of English interference in to Romanes, there is much interference from Romanes into English. Part of the non-standard character of the English spoken by the Portland Gypsies is a result of the fact that most originally learned English from speakers of non-standard English (see also Hancock 1976: 90). The fact that young people speak this same dialect of English that their parents speak, despite the more extensive contact with standard English on TV and at school, strengthens my thesis that the children learn English from their parents (cf. Rubin 1980: 55).

1. Phonetic interference.

$/ v /$ becomes /w/ "involved" / nwald/

"vomit" /wamct/

Romanes words such as slawa and Mačwaya are sometimes pronounced with the /V/ sound in other dialects (Gropper 1975, Silverman 1979, and Sutherland 1975). However difficult it seems for the Portland Gypsies to pronounce $/ v /$, it is used initially in words such as vitsa and the proper names 任ici and Vanya.

$/ r /$ sometimes becomes /w/

"shrimps" /swcmps/

/o/ becomes the dipthong /ou/ if held for a long time, most characteristicly on an emphatic "no". 
$\mid \partial /$ becomes /d/

$$
\begin{array}{ll}
\text { "the" } / d o / \\
\text { "that" /dxt/ } \\
\text { "they" /de/ }
\end{array}
$$

$/ \theta /$ becomes $/ t /$ initially

$$
\begin{aligned}
& \text { "think" /tink/ } \\
& \text { "three" /tri/ } \\
& \text { "theater"/tiotr/ }
\end{aligned}
$$

$/ \theta /$ becomes $/ t /$ medially

$$
\text { "nothing" /noten/ }
$$

$/ \theta /$ becomes $/ t /, / s /$, or $/ f /$ finally

$$
\begin{aligned}
& \text { "with"/w<t/ } \\
& \text { "birth" /bof/ } \\
& \text { "teeth" /tis/ }
\end{aligned}
$$

2. Structural/phonetic interference.

Mouths are generally held tighter and more rounded when speaking either Romanes or English, resulting in more front-rounded sounds. This effect is even more pronounced when the speaker is angry or excited. 3. Lexical interference.

Although Romanes words are sometimes used when the English word is not known, most Romanes words have English equivalents. Unknown translations vary from person to person. Romanes interferes lexically more often through calques (adoption-translation). These transfers can occur in different form classes. 
Verbs.

"blslun" can mean "they stand" or "they stood" (cf. Hancock 1976: 100)

How long you stood there?

[How long did you stay there?]

"karel" is the third person singular form of the common verb of cause which usually translates as "he makes" and is used when standard English speakers would use "he does" or "he has".

It's my cousin, Anne. He's making the operation. [He's having the operation.]

Make the vacuum.

[Do the vacuuming.]

He made a wreck.

[He had a wreck.]

Nouns.

"népato" means both "nephew" and "grandson" (Cohn 1969: 478). Occasionally a Gypsy uses the terms interchangeably. Although the words for "grandfather" (ṕapo) and "uncle" (kak) are not the same, I have also heard these terms used interchangeably, possibly as a result of the confusion between "nephew" and "grandson". There is certainly no confusion about the actual relationship.

Prepositions.

"pala" can mean "for" or "after". Sometimes the meaning is also the same in English. For example, "She went to 
the store for cigarettes." has the same meaning as "She went to the store after cigarettes." Yet, in this dialect of English, "after" is used when standard speakers would use "for".

He died after us.

[He died for us.]

That's the girl Wally wants after Harry•

[That's the girl Wally wants for Harry.]

4. Structural interference.

Use of the third person impersonal noun when standard English speakers would use a pronoun.

Although Romanes has third person pronouns, they are rarely used. Verbs show person and number:

$$
\text { Want (There is no infinitive form.) }
$$

(me) mangau

(ame) mangas

(tu) mangrs

(tume) mangkn

(wo, woi) mangel

(won) mangen

When eliciting a translation for "He is happy.", for example, I was given "V́esolo sa o śawo." (The boy is very happy.). This tendency is reflected in English. "But the man doesn't want to wait." (about their father) "That boy knows where it is." (about a cousin who was present)

"The bad part, the woman bought a blanket already." (about her mother) 
Prepositions.

Romanes has an accusative ending - ka for nouns. Its use is transfered onto English sentences.

"I have proof to her." (to her, lake)

[I have proof for her.]

"That's what I told to Diane. (to Diane, Dino-ka)

[That's what I told Diane.]

"Give me the number to Larry." (to Larry, Larry-ka)

[Give me the number for Larry.]

The source of something such as emotion is indicated by the use of "ḱato" (from) in places where standard English speakers would use "of" or "at". (See also Bhatia 1963: 39 and Gjerdman and Ljungberg 1963: 222 and 256.) For example:

"či d́aro ḱato mo dad, ḱato George." (neg.) fear from my dad from George [I'm not afraid of my dad, (but) of George.]

"Kato Debbie asám."

from Debbie I laughed

[I laughed at Debbie.]

This indication is transfered onto English. "She's ascared from my ariving." "They're all scared from him." Word order.

Romanes word order sometimes interferes in English 
sentences. The subject often comes at the end of the whole sentence.

"Xoĺalo Mechanic."

He's mad Mechanic

[Mechanic is mad.]

"Musái karés mánga tu."

must you make for me you

[You must make it for me.]

This word order is sometimes used when forming English sentences.

"She's always tired -- Joann."

[Joann is always tired.]

"She's right in my mouth -- the word."

[The word is right in my mouth.]

This additional clarification is also added to the end of sentences using object pronouns.

"I met them -- the girls."

[I met the girls.]

"I'm afriad of them -- the phone."

[I'm afraid of the phone (company).]

In Romanes, the pronominal phrase follows the verb instead of following the adverb as in English. "Anál tuká papaĺe."

He brought to you back

[He brought it back to you.]

This word order is used when forming English sentences. 
"Put this for me down."

"Write this for me down."

"You have to talk to them before they talk to you back. "Put this for me on the bed."

"Someone can call me in."

[Someone can call in to me (on the phone).]

Omission of auxillary verbs in interrogative sentences.

Romanes speakers form questions by putting a question word or phrase in front of a declarative sentence and changing the inflection.

"Mangél EEl."

he wants he goes

[He wants to go.]

"Matilo."

he is drunk

[He is drunk.]
"Kon mangel gel?"

who he wants he goes

[Who wants to go?]

"Kon matilo?"

who he is drunk

[Who got drunk?]

This formula is used in forming English questions. The auxillary verb is omitted and the simple past tense used. "What night he called up?"

"How many times she paid the rent?"

"What your father said?"

This structure is also seen in sentences which mix English and Romanes.

"So mean?"

what (you) mean

What do you mean? 
"How but bislen?"

how much (you pl.) stay

[How long did you stay?]

Past tense.

Romanes uses verb endings, not auxillary verbs, to form past tense. This difference causes two common errors in English.

The past perfect form is often used without auxillary verbs.

"You seen this part."

"He done it already."

"I done finished."

When auxillary verbs are used, they are used with simple past forms.

"Why didn't you told us?"

"You didn't won nothing."

"How'd she felt?"

"Did you guys got both?"

"You didn't brought nothing home."

Negation.

The use of double negatives is common. This may possibly be a result of learning English from non-standard speakers (Hancock 1976: 90) and may be reinforced through popular media such as radio and television. "Či karés ḱ́hanči." (neg.) you do nothing [You don't do anything.]
[Yo 
"She's not saying nothing."

"They don't give you no trouble."

"She's not no older than you."

"Nobody never seen that club."

Other Characteristics of Portland Gypsy English

There are also characteristics which are a result of imperfect learning of English without any interference from Romanes. Although these deviations from standard English are common to many who have an incomplete understanding of standard English, they are found so often among Gypsies of all ages that they seem to be part of the dialect which is passed from generation to generation. Again, this would support the theory that children learn English from their parents through the method of mixing both languages.

1. Analogic change.

A. Verb tenses.

"My father broked us up."

"What time you usted to turn in?"

"She can't comes back."

"It lookted good on Delores."

"The way she gived it back was terrible."

"He wents on the mountains."

B. Possessive pronouns.

"Her dress is like mines."

"When I get mines." 
C. Comparative adjectives.

"It's better to go on, hire a little expenser."

D. Plurals.

"It hurts my feets."

"The lockses don't work and all the flies coming in."

2. Vocabulary.

A. Semantic extension.

"Spill some water." (pour out)

"Cut up the wegtables like dices." (dice the vegetables)

B. Malaprops (Fay and Culter 1977)

"You have a house or department?" (apartment)

"Cut it like a circus." (circle)

"It all pretends." (depends)

"It costed $\$ 20$ to alternate it." (alter)

C. Blends.

"Don't worry -- I backed you out."

( backed you up/got you out of $i t$ )

"You usted to hide up lots of money."

(save up/ hide)

D. Words close in meaning.

"Car porch" (carport)

"Walk away closet" (walk-in closet)

"Godfather" (priest) 
E. Mispronunciation.

$$
\begin{array}{r}
\text { Inverted sounds: /prenag/ (pregnant) } \\
\text { /skrits/ (receipts) }
\end{array}
$$

Dropped syllable: /scla/ (celery)

$$
\begin{array}{ll}
\text { /kæmo/ } & \text { (camera) } \\
\text { /beres/ } & \text { (embarrass) } \\
\text { /praizd/ (surprised) } \\
\text { /pointld/ (disappointed) }
\end{array}
$$

Sound substitution:

$$
\begin{array}{ll}
\text { /bambobal/ } & \text { (bumblebee) } \\
\text { /kreduk/ } & \text { (credit) } \\
/ \text { krwk/ } & \text { (click) }
\end{array}
$$


TEXTS

\section{Conversation one}

The father had been speaking English to the doctor on the telephone.

Father: They have to do the injection and the scan. They have to inject the liquid.

Grandma: Śosu liquid?

which

[Which liquid?]

Father: $\underline{0}$ ink.

[The ink.]

Grandma: ㅇink.

Aunt: So phendel 을 doctor?

what he says the

[What does the doctor say?]

So phendel they're gonna make it right away?

what he says

[What if he says they're going to do it right away?]

Father: They have to make tests.

Aunt: This doctor will probably say

či manǵll te $\underline{\text { karel }}$ o operation.

(neg.) he wants that he makes the

[he doesn't want to do the operation.] 


\section{Conversation Two}

A young woman

B young woman

C B's five-year-old niece

A Akaná paigí milái hai we never went no place. now too fast summer and

[The summer has gone too fast and we didn't go anyplace.]

Araslam 으 Blue Lake.

we arrived the

[We went to Blue Lake.]

Tósas pai hai žesa.

we used to put water and we used to go

[We used to put water (in the radiator) and go.]

$B$ So si ki problem?

what is your

[What's the matter (now)?]

A $\check{c} i \quad$ del ḱlonck.

(neg.) he gives nothing

[Nobody's interested.]

B Khalisad i Dana?

called Rosie

[Did you call Rosie?]

A Gerídu D́ana či mai karel poor, pitiful Rosie (neg.) more she makes telephone [Poor Rosie, she never makes a phone call.] 
B Stop that, Tami.

Garí hot dog. Tósis tu maro.

get you put you bread

[Go get a hot dog. Put it on bread.]

C You get me one.

B Iu sam barí śuru.

you are big girl

[You're a big girl.]

C Kai i Mamí?

where Grandma

[Where's Grandma?]

B Xaŕl carí.

she washes dishes

[She's washing dishes.]

OK, Dora.

A Zau kai track. Zau te dobi loẃe.

I 80 where I go that I win money.

[I'm going to the races. I'm going to win some money.]

Mang's $\quad$ Ess?

you want you go?

[Do you want to go?]

B Xalad'sm sa murú śada.

I washed all my clothes

[I washed all my clothes.] 
Su kelél le śada.

are it dries the clothes

[The clothes are drying.]

A Kana?

when

[When (will they be dry)?]

$B$ Xoli mánga te régula.

hateful to me that I dress up

[I hate to dress up.]

A Zai hai ńada.

go and don't worry

[Go and don't worry about it.] 


\section{Conversation Three}

JK Grandfather

R Grandmother

B Uncle

$J$ Aunt

A Father

D Mother

JB Little boy

$T$ Iittle girl

B You know what that's?

JB Chopsticks. How do you work these?

JK Sai xas tu with chopsticks?

can you eat you

[Can you eat with chopsticks?]

JB No.

JK You take 'em like that.

JB How?

JK Xas gadýa. You take your chopsticks gadyá. you eat like this like this

[You eat like this. You take your chopsticks like this.]

JB Really?

JK Yeah.

JB Here's how I do it.

$J \quad \underline{\mathrm{Nai}}$ 으묘.

is not the rice

[There's no rice.] 
J You can have the whole box of that, Daddy.

You didn't brought the rice.

Kai $\quad \underline{\text { rizor }}$

where the rice

[Where's the rice?]

D Barásko, é talo. $\frac{\text { Alaklám }}{\text { o } \underline{\text { rizo. }}}$ [Joann, here it is.

J That's gravy.

D I put gravy on it.

$\mathrm{J}$ Oh, sorry.

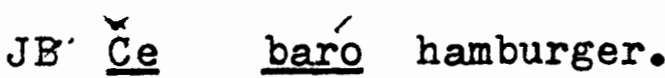

very big

[What a big hamburger.]

Jk če baŕo.

[Very big.]

JB No fries?

$R$ D́aino, ḱana žasas tu Khábole hai Skipper? Diane when we go you Khabole and [Diane, when are we going to Khabole and Skipper's?]

JK Śosti na ažukarés ma te pauwáu teḱuto? why (neg.) you wait me that I cash ticket [Why didn't you wait for me so I could cash the ticket?]

B It's too nervous and I thought you were losing. [It made me too nervous because I thought you were losing.]

JK Yっ 
A We can always wait until tomorrow and tomorrow we'll get it all back.

JK Tomorrow is...

$B$ Yeah, I was too nerrous and I lost it. Twenty-five hundred dollars.

JK Xolai le.

you used it

[You spent it.]

B Žukal karḱsa amaláu le me.

dog used to make I get it I

[I used to make it (money) on the dogs.]

R Xolai Ie.

you used it

[You spent it.]

JK Ama pa-uál o me ticket karí mánde.

to me he cahsed I at home for me

[He brought the ticket home for me to cash.]

A Pa-u lis. Pa-u lis.

[Cash it. Cash it.]

$J$ You want some of this rice? Hey, this tastes terrible.

JB I want some fries. I want some fries.

A There's no fries, son, just rice.

JB Na, Dadi.

(expression of disbelief or disappointment) Daddy $[\mathrm{Oh}$, no, Daddy.] 
$R \quad$ So is?

[What is it?]

J Hey, potato chips. That's why they didn't get no fries.

$B$ They hate you. (teasing JB)

$J \quad I$ da śoda.

[There's pop.]

$\mathrm{R}$ Take it out. $\underline{\mathrm{C}}$ mangau $\underline{\text { xau }}$ śteko.

(neg.) I want I eat steak

[I don't want to eat steak.]

D Nai steko, Ḿamo.

is not steak Mom (voc.)

[It's not steak, Mom.]

J I don't like it; she don't likes it.

$R$ Dali, xoli manga te xau late.

(interj.) mother it's hateful to me that I eat

[Mother, I hate to eat late.]

D Mamo, xa:

[Mom, eat!]

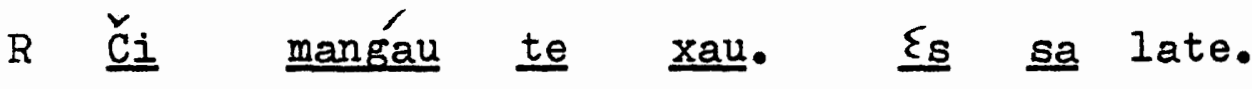

(neg.) I want that $I$ eat is all

[I don't want to eat. It's too late.]

Či wol'u $\quad \underline{\text { xabe. }}$ o baŕo xabe.

(neg.) I like the food the big food

[I don't like the food. The food is too heary.] 
WoÍu soda hai potato chips.

I like pop and

[ I like pop and potato chips.]

J What number? What number?

B Four, six, 0 .

$\mathrm{J}$ What number you bet on?

A Five, six, eight.

$\mathrm{J}$ Ĺeski number.

his

[His number.]

B Twenty-five hundred.

J Did you guys have the konella, too.

B Hai konella paid three hundred dollars. [and]

J Kai xalem? You got some money?

where you ate

[Where did you eat?]

JB Yeah.

A I can't believe we paid for it. (the food)

$R$ We had xabe in the icebox.

food

[We had good food in the refrigerator.]

JK Sa pharadem.

all it broke

[All (the rice) fell off.] 


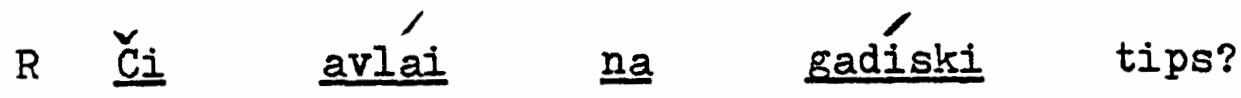

(neg.) they came (neg.) non-Gypsy man's

[Didn't the man's tips come in?]

B I hit three hundred dollars.

JK And what do I tell them, first thing they go to the track? Just bet the long shots only, nothing else.

D We'll go out to the track and we'll get the five, six this time. You live and learn. You live and learn.

R Alex phendém...

he said

[Alex said....]

$J$ You only had six dollars. How did you went to the track without money, busted?. You didn't take no money out of your purse.

Gadýa karén kai track without lowe.

like this you (pl.) went where money

[Iike this you guys went to the track, without money.]

D I only had six dollars and that was it. Bobby got to have twenty-five dollars and he ran.

A Sa mang'́l le.

all he wants it

[He wants all of it.]

Kill them in one race. Dikh! Háaid, hádi, haidid

[Look! Come, come, come!] 
$R$ So gudýa o f́reno?

what happened the friend

[What happened to your friend?]

JK What'd you do with the ticket?

A Phendem, "Let's go cash it."

he said

[He said, "Let's go cash it."]

$D$ orát, d́osta.

alright enough

[Alright, that's enough.]

$R$ So? Musai sa te xal twelve o'clock.

what must all that he eats

[What? He has to eat it all at twelve o'clock.]

JK I was better off giving it to Pete.

A How could you say that?

JK When I paid the tax, they deducted it off mines.

A But you paid the tax on it. And all you're getting is the deductible.

JK Right. You know what the boys been doing the last two, three years? You know what the boys been doing every year? Nobody pays a dime. All the winning ticket.

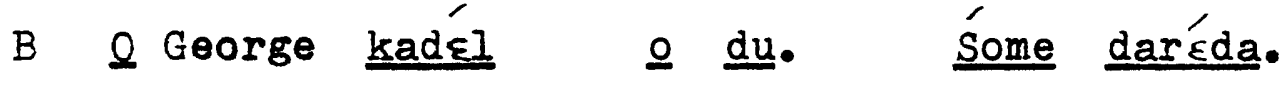
he made the same sixty dollars

[George won the same thing. Sixty dollars.]

JK Pete cash... get that credik for income tax. All they 
have to do is put a name on it.

$R$ Kon sas khote?

who was there

[Who was there?]

B Q Pete sas khote. o śpido sas khoté. O Frankie [Pete was there. Spido was there. Frank

sas khote. Sa suru sas khote.

was there. All the boys were there.]

D Special painc darḱdi 을.

five dollars the food

[The food was on special for five dollars.]

$J$ Sa dau ḱako xabe akańa.

all I give this food now

[I'm throwing away all this food now.]

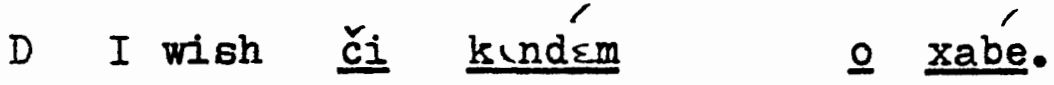

(neg.) I bought the food

[I wish I hadn't bought the food.]

JB Dad, Dad, do you think you could fix that Atari in back? Mangau khaláu manga Ínsa.

I want I play forme with them

[I want to play with them.]

B One hour to play with it round.

[You can play around with it for an hour.] 
45

JB Malmo, yuk silver dollar haj mangáu te garáu lis. Mom one and $I$ want that $I$ save it [Mom, ( I had) one silver dollar and I wanted to save it.]

Colo hat kund́́m o soda.

$I$ went and I bought the pop [I went and bought pop.]

$\begin{aligned} & \text { B } \text { ai } \\ & \text { go so. } \\ & \text { [Go to bed.] }\end{aligned}$

$D \quad \mathrm{Na}$ badísa lis.

(neg.) bother him

[Don't bother him.] 
Narrative: A Dream

Baŕi f́ila. Strrangu mobili, baŕ khario. big field strange car big van

[There's a big field. There's a strange car, a big van.]

Listen. Me hai tu hai Doris hai Dana,

$I$ and you and and Rosie

[Listen. You and Barbo and Rosie and I.

we're running to the car ano filo.

in the field

we're running to the car in the field.]

But I don't know what we're doing in that field. But it's desert, you know, like hunting.

Phirás áno 集o hai dark.

we walk in the field and

[We're walking in the field and it's dark.]

So gudos? What happened?

what happened

[What happened? What happened?]

žau o mobili.

I go the car

[I go to the car.]

And we're trying to get somebody out of it. But the car went. The car went th us, but nobody's driving. The car's going alone. 
So gudE?

what happened

[What happened?]

We're trying to help Dana now

cause half $ᄋ$ body avrí 으 windshield. the outside the

[because half of her body is outside the windshield.]

We got Dana out. The car's going, going, going.

It's scarey. We can't open the doors. "Just open the windows hai jump out the windows." They won't open. and

Geridu

Barbo

poor, pitiful Doris

[Poor Doris, ]

Wazdýas le waz le skíu te dikhas amé. she raised the (pl.) hands the sky that we see to e [She raised her hands to the sky to show us (she's not doing it).]

Lamén o mobili ṕsa.

they take the car with it

[The car takes us with it.]

Four guys at the wheel and we can't control it.

It was daytime when we got in the car, but 
kai kadrm, kai kad'́m o mobili sas $\underline{i}$ rat out. where it made where it made the car was the night [Where the car went, it was night out.]

Mang'as ladýas wadikas ano mobiliz.

we want we took somebody in the car

[We wanted to take somebody from the car.]

Ḱana tod'sma áno mobilii, nas khonck.

when I put me in the car was not nobody

[When I got into the car, nobody was there.]

But we're all killing her. There's no way in the world she can't control the wheel 'cause the car going one hundred miles an hour.

Todýas i breki.

she put the brakes

[She put on the brakes.]

Me $\underline{d \varepsilon m}$ o $\underline{\text { saru. }}$

I I gave the head

[I hit my head.]

Windshield khrakiśaidi.

cracked

[The windshield cracked.]

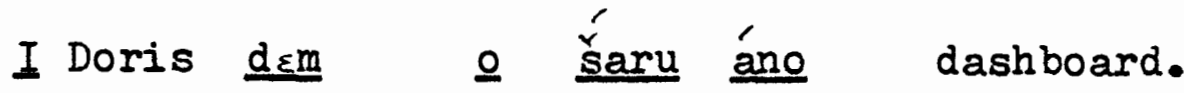

she gave the head on the

[Doris hit her head on the dashboard.] 
I Barbo $\underset{\mathrm{d} m \mathrm{~m}}{\mathrm{o}}$ šaru
she gave the head ano gata.

Barbo hit her head on the steering wheel.

Doris kai ǵata.

Barbo where wheel

[Barbo is at the steering wheel.]

Liýan i ǵata.

they took the wheel

[She took the wheel.]

She's trying to control the steering, control the brakes.

"Kai ladýan áno mob́ili?

where you took in the car

["Where are you taking (us) in the car?]

Hey, Barbo, where you taking us?"

"The car's going all over." That's how she said it.

"Barbo, dósta, śtopisad o mobili." enough stop the car

["Barbo, that's enough, stop the car."]

Errrrrrred That brakes. When she hit the brakes.

She end up on the windshield.

Half o Dana o body avri.

the outside

[Half of Rosie's body was outside.]

Me dem o šaru áno windshield.

[I hit my head on the windshield.] 
From the front... from the back and jump all the way on the front.

Ustad'sma $\quad$ Viči.

she woke me Ruby

[Ruby woke me up.]

God knows what happened to us. 


\section{IEXICON}

All of the following words were elicited from the Kalderash Rom of Portland, Oregon.

A

abladilo

abolau

abyaw

agะz

akana

akor

akušimos

aleki

alungo

amuko

anal

analka

anda

ano

aygosti

$\operatorname{arak} \varepsilon l$

arat

arasel

asal suicide, hanging

baptism

wedding

today

now

nut

cursing

yesterday

along

cotton

he brings

orange

because

in the, on the

ring

he finds

tonight

he arrives

he laughs 


\begin{tabular}{|c|c|}
\hline aśila & she is goor \\
\hline ašilo & he is good \\
\hline ašo & good \\
\hline ăstarkl & he catches \\
\hline ašunel & he hears \\
\hline av $\varepsilon I$ & he comes \\
\hline ažukarel & he waits \\
\hline \multicolumn{2}{|l|}{$\underline{B}$} \\
\hline bakro & $\operatorname{lamb}$ \\
\hline bakso & box \\
\hline bal & hair \\
\hline balo & pig \\
\hline balano maz & pork \\
\hline bamputi & boating \\
\hline baro & big \\
\hline barvalo & rich \\
\hline bæ sketa & basket \\
\hline bebitsu & baby \\
\hline beng & devil \\
\hline bengalo & evil \\
\hline bešeI & he sits \\
\hline bešmino & behave \\
\hline$b \varepsilon d u$ & bed \\
\hline bsdu sen piaden & water bed \\
\hline bigaro & butter \\
\hline bikinsl & he sells \\
\hline
\end{tabular}




\begin{tabular}{|c|c|}
\hline biromni & bumblebee \\
\hline bcslcn & they stood, they stayed \\
\hline blauzo & blouse \\
\hline borania & green beans \\
\hline brastعI & he runs \\
\hline buki & work \\
\hline but & much \\
\hline \multicolumn{2}{|l|}{$\stackrel{\check{C}}{\underline{C}}$} \\
\hline čar1 & dishes \\
\hline če & what, how \\
\hline česo & hour, time \\
\hline$\check{c}_{i}$ & $($ neg. $)$ \\
\hline čidalo & he's stingy \\
\hline čirikli & bird \\
\hline čohano & ghost \\
\hline čoro & poor \\
\hline čuri & knife \\
\hline \multicolumn{2}{|l|}{$\underline{D}$} \\
\hline dab & fist \\
\hline dadi & father (vocative) \\
\hline dadesko & father's \\
\hline daimo & dime \\
\hline dal & he gives \\
\hline dal duma & he speaks \\
\hline dar $\varepsilon d a$ & dollars \\
\hline
\end{tabular}


$\operatorname{dar} \varepsilon I$

dawo

deno

mai deno

dikh

dikh $E I$

diklo

dilo

dobis

doktaletsa

doktoro

dosarel

dosta

draba

drabnimos

drom

drumo

dugato

dui

dukal

dukauma

dumano

dumo

dupwaz

$\underline{\varepsilon}$

Eftino he fears

brideprice

young

younger

lookd

he looks

scarf

crazy, clown

you win

female doctor

male doctor

he accuses

enough

medicine, chemicals

fortune telling

road

arm

law

two

he hurts

I hurt myself

enemy

shoulder

twice

it's cheap 
$\underline{F}$

fabol

fadi

falka

fedia

fistano

foro

freno

fretso

fuzwi

$\underline{G}$

gad

gadia

gambro

garkl

gari

gaze

gazi

gazo

geridu

gesukita

gEZ

globl

golo

grapa

gratsa he paints

purse

chin

carnival

dress

town, shopping center

friend

saint

beans

shirt

paper, newspaper

pear

he saves

get!

non-Gypsy people

non-Gypsy woman

non-Gypsy man

poor, pitiful

apron

day

light bulb

I went

hole

ugly 
guc

hai

haida

$h \in d a \varepsilon I$

I

i

inko

K

kai

kaini

kak

kako

kalo

$\operatorname{kam} \in I$

kan

karel

karitsi

kat

kar

kari

kilo, ki

kinel

kiro it's expensive

she went

and

come

he understands

(feminine article)

ink

where

chicken

uncle

this

black

he makes Iove

ear

he does, he makes

curly

scissors

house

at home

your (m.)

he buys

cheese 
kivo

kivi

kokalo

kon

kona

korko

kris

kušo

$\underline{\mathrm{Kh}}$

khalel

khanči

khangari

khelel

khonik

khostel

khote

khrompel

I

la

laka

lako

lasa

lašarยl

lažo

$I \varepsilon I$

lima godfather

godmother

elbow

who

corner

alone

trial, jail

brother-in-law

he plays

nothing

castle, church

he dances

nobody

it costs

there

he argues

her

to her

hers

with her

he fixes

shame

he takes

bracelet 
Iis

I हski

Iesti

loan

lowe

lulugi

$\underline{M}$

mai

mami

mamo

mamura

man, ma

$\operatorname{man} g \in I$

$\operatorname{mar} \varepsilon I$

marimos

maro

mašo

maz

matilo

me

melano

merikansi

milai

mobili

moro, mo

muru, mu him

his

to him

salt

money

flower

more

grandmother (vocative)

mother

monkey

me

he wants

he fights

fighting

bread

fish

meat

he is drunk

I

dirty

American (adj.)

summer

car

my (m)

my ( $f$ ) 
mudarel

mui

musai

mutsa

mutsara

$\underline{N}$

nada

nai

nai

naistuka

nas

nasli

nepata

nepato

numa

$\underline{0}$

0

orait

$\underline{P}$

pai

paičif

paigi

pala

papale

papino he kills

face, mouth

must

cat

broom

don't worry

finger, toe

is not

thank you

was not

escape, elopement

granddaughter

grandson

but

(masculine article)

alright

water

honor

too fast

after, from

back (adv.)

cantalope 
papo

paposko

papusa

parno

paš

paual

peparka

madi peparka

pistadi

pleso

pokinel

poktan

poro

prano

puธ̌ย]

putral

$\underline{\mathrm{Ph}}$

phabi

phabol

phand $\varepsilon 1$

pharade

phe

ph $\vDash n d \varepsilon l$

phidel

phral

phraleski grand father

grandfather's

doll

white

beside, by

he craves

pepper

red pepper

hospital

business

he pays

pillow

foot

oldest

he asks

he opens

apple

it burns

he closes

broken

sister

he says

he walks

brother

brother's 
phuro

old

$\underline{\mathrm{R}}$

rat

night

ravnos

heaven

regula

dress up

rizo

rice

Rom

Gypsy man

rom

husband

Romni

Gypsy woman

romni

wife

$\underline{S}$

sa

saburut

all

hemorrage

sada

clothes

sai

saihitu

can, may

spicy hot

salato

clock, wristwatch

I am

$\operatorname{san}$

you are

sania

coffee

sas

he was

satino

silk

sauwa

some

selele

celery

si

he is 
sigara

skamin

skula

so

so

soba

solo

sosti

sosu

soval

stakstai

sta gi

stristo

strito

su

suval

svita

$\underline{\text { s }}$

šaro, šaru

šawo

še

šuka

šukali

šuki cigarette

chair, couch

school

what

sleepd

bedroom

rug, carpet

why

which

he sleeps

cup

hat

sad

street

needle

he sews

sweater

head

boy

girl

beautiful

she is beautiful

skinny 
T

tehana

tomiamos

tol

triu

tu

tut

tume

tuhano

tumialo

tulo

U

ustadema

V

vesolimo

vesolo

W

wad $\varepsilon s o$

wadikas

wado

waz

le waz

$\operatorname{maz} \varepsilon]$

พอ

woi tomorrow

bride negotiations

he puts

I try

you (subject)

you (object)

you (plural)

cigar

he is angry

fat

he woke me

happiness

happy

something

somebody

cousin

hand

hands

he raises

he

she 


\begin{tabular}{|c|c|}
\hline wolEl & he likes \\
\hline won & they \\
\hline wudar & door \\
\hline \multicolumn{2}{|l|}{$\underline{x}$} \\
\hline xabe & food \\
\hline xal & he eats \\
\hline xanomik & co-parent-in-law \\
\hline xar $\varepsilon l$ & he washes \\
\hline xolalo & he's mad \\
\hline xoli & hateful \\
\hline xoxaimos & false \\
\hline $\operatorname{xoxav} \varepsilon 1$ & he lies \\
\hline \multicolumn{2}{|l|}{$\underline{\underline{Y}}$} \\
\hline yak & eye \\
\hline yardo & garden \\
\hline$y<k$ & one \\
\hline$y<k$ woz & once \\
\hline \multicolumn{2}{|l|}{$\underline{\underline{z}}$} \\
\hline žai & gol \\
\hline žau & I go \\
\hline$\check{z} \varepsilon l$ & he goes \\
\hline žurkl & $\operatorname{dog}$ \\
\hline
\end{tabular}




\section{SOURCES CITED}

Bain, Bruce and Agnes Yu 1980. "Cognitive Consequences of Raising Children Bilingually," Canadian Journal of Psychology, 34(4): 304-13.

Bhatia, Rishi 1963. A Gypsy Grammar. Ph.D. Dissertation, University of Pennsylvania.

Clyne, Micheal 1980. "Triggering and Language Processing" Canadian Journal of Psychology, 34(4): 400-7.

1967. Transference and Triggering. The Hague: Marinus Nijhoff.

Cohn, Werner 1969. "Some Comparisons between Gypsy and American English Kinship Terms," American Anthropologist, $71: 476-482$.

Duncan, Starkey, Jr. 1972. "Some Signals and Rules for Taking Speaking Turns in Conversations," Journal of Personality and Social Psychology, 23(2): 283-292.

Ervin, S. and C.E. Osgood 1954. "Second Language Learning and Bilingualism," Journal of Abnormal and Social Psychology, 49: 139-146.

Fay, David and Anne Cutler 1977. "Malapropisms and the Structure of the Mental Lexicon," Linguistic Inquiry, $8(3): 505-20$.

Fishman, Joshua 1964. "Language Maintenance and Language Shift as a Field of Inquiry," Linguistics, 9: 32-70.

Fox, Charles 1978. Gypsy. Videotape segment. Narrated by Leita Kaldi. Boston, Massachusetts.

Gjerdman, Olof and Erik Ljungberg 1963. The Language of the Swedish Coppersmith Gypsy Johan Dimitri Taikon. Uppsala: A-B Iundequistska.

Greenfield, Lawrence and Joshua Fishman 1972. "Situational Measures of Normative Language Views in Relation to Person, Place and Topic among Puerto Rican Bilinguals, " in Samir Ghosh (ed.), Man, Language, and Society: Contributions to the Sociology of Language, 64-86, The Hague. 
Gropper, Rena 1981. "The Care and Feeding of an Anthropologist," in Matt T. Salo (ed.), The American Kalderas: Gypsies in the New World, 1-10, Centenary College, Hackettstown, New Jersey.

1975. Gypsies in the City. Princeton, New Jersey: Darwin.

Hancock, Ian 1976. "Patterns of English Lexical Adoption in an American Dialect of Romanes," Orbis, 25(I): 83-104.

-.... 1975. "Problems in the Creation of a Standard Dialect of Romanes," Social Science Research Council Committee on Sociolinguistics, Working Paper no. 25 .

Hasselmo, N. 1970. "Code Switching and Modes of Speaking" in G. Gilbert (ed.), Texas Studies on Bilingualism, $275-286$.

Haugen, Einar 1972. The Ecology of Language. Stanford, CA: Stanford University Press.

Jesus King of the Gypsies. Cassette tape. God's Gypsy Christian Church (Le Devleski Romany Khangeri). Los Angeles, California.

Kendrick, Donald 1981. "The Development of a Standard Alphabet for Romani," The Bible Translator, 32(2): 215-219.

Kolers, Paul 1963. "Interlingual Word Associations," Journal of Verbal Learning and Verbal Behavior,2: 291-300.

Kolers, Paul and Michel Paradis 1980. "Psychology and Iinguistic Studies of Bilingualism," Canadian Journal of Psychology, 34(4): 249-264.

Lipski, John M. 1980. "Code-Switching and the Problem of Bilingual Competence," Canadian Journal of Psycholosy, $34(4)$ : 249-264.

Maas, Peter 1975. King of the Gypsies. New York: Viking.

MacNamara, John 1967. "The Linguistic Independence of Bilinguals," Journal of Verbal Learning and Verbal Behavior, 6: 729-36. 
McClure, Erika and M. McClure 1975. "Ethnoreconstruction," Mid-America Linguistics Conference Papers, 327-37,

Lawrence: University of Kansas.

Meltzer, Leo; William N. Morris; and Donald P. Hayes 1971. "Interruption Outcomes and Vocal Amplitude: Explorations in Social Psychophysics," Journal of Personality and Social Psychology, 18(3): 392-402.

Paradis, Michel 1978. "Relational Network Approaches to Code-Switching," in Michel Paradis (ed.) Aspects of Bilingualism, 237-49, Columbia, SC: Hornbeam Press, Inc.

Pfaff, Carol W. 1979. "Constraints of Language Mixing: Intrasentential Code-Switching and Borrowing in Spanish/English," Language, 55(2): 291-318.

Pickett, David Wayne 1970. The Gypsies: An International Community of Wandering Theives. Ph.D. Dissertation, Syracuse University, NY.

Rayfield, J.R. 1961. The Languages of a Bilingual Community. Ph.D. Dissertation, UCLA.

Rubin, J. 1968. National Bilingualism in Paraguay. The Hague: Mouton.

Rubin, Steven D. 1980. The Assimilation and Education of Portland's Gypsies: A Participant-observation Study. B.A. Thesis, Reed College: Portland, Oregon.

Schegloff, Emanuel A. 1968. "Sequencing in Conversational Openings," American Anthropologist, 70(6): 1075-1095.

Silverman, Carol T. 1979. Expressive Behavior as Adaptive Strategy among American Gypsies. Ph.D. Dissertation, University of Pennsylvania.

Sridhar, S.N. and Kamal K. Sridhar 1980. "The Syntax and Psycholinguistics of Bilingual Code Mixing," Canadian Journal of Psychology, 34(4): 407-416.

Sutherland, Anne 1975. Gypsies: The Hidden Americans. London: Tavistock.

Vaid, Jyotsna and Fred Genesee 1980. "Neuropsychological Approaches to Bilingualism: A Critical Review," Canadian Journal of Psychology, $34(4): 417-424$. 
Weinrich, Uriel 1963. Languages in Contact. The Hague: Mouton.

Wolck, Wolfgang 1973. "Attitudes toward Spanish and Quechua in Bilingual Peru," in Roger W. Shuy and Ralph W. Fasold (eds.), Language Attitudes: Current Trends and Aspects, 113-147, Washington, D.C.

Yoors, Jan 1967. The Gypsies. New York: Simon \& Schuster. 